\title{
ANÁLISE DA OCUPAÇÃO DE LOTEAMENTOS REGULARES NO ESTADO DE SÃO PAULO ANTES DA LICENÇA DE OPERAÇÃO
}

CARRIJO, Adriano José ${ }^{1}$ FRIAS, Danila Fernanda Rodrigues ${ }^{2}$

\begin{abstract}
RESUMO: Devido à preocupação com o meio ambiente, o Poder Público impõe a obrigação de prévio licenciamento ambiental para empreendimentos. Deste modo, este trabalho teve por escopo examinar a legislação estadual paulista acerca do licenciamento ambiental de loteamentos no que toca à impossibilidade de sua ocupação antes da Licença de Operação. A pesquisa foi desenvolvida no Estado de São Paulo, pela análise de autos de infração e imposição de advertências ou multas em loteamentos regulares, devido a ocupação antes da licença de operação. Foram localizados 802 autos de infração aplicados, com variação das penalidades, de mera advertência a multa pecuniária. Sendo inviável ou inadmissível a visão de interpretação da legislação vigente, foi desenvolvido um texto referente a sugestão de alteração na legislação estadual. Pode-se notar a importância da correta leitura e interpretação do ordenamento jurídico, para que não ocorra aplicação de multas indevidas a loteadores que cumprem as regras legais.
\end{abstract}

Palavras-chave: Acusações indevidas. Infração administrativa ambiental. Insegurança jurídica de loteadores. Legislação estadual paulista ambiental. Loteamentos paulistas.

\section{ANALYSIS OF THE OCCUPATION OF REGULAR ALLOTMENTS IN THE STATES OF SÃO PAULO BEFORE THE OPERATION LICENSE}

\begin{abstract}
SUMMARY: Due to the concern with the environment, the Public Power imposes the obligation of prior environmental licensing for enterprises. In this way, this work had as scope to examine the São Paulo State legislation on the environmental licensing of allotments with regard to impossibility of their occupation before the Operation License. The research was carried out in the State of São Paulo, through analysis of tax assessments and the imposition of warnings or fines in land of legal subdivisions, due to occupation before the operation license. There were 802 notices of infringement applied, with varying penalties, merely warning the pecuniary fine. As it is not possible to interpret the current legislation, a text was developed regarding the suggestion to change the state legislation. It may be noted the importance of the correct reading and interpretation of the legal system, so that there is no application of undue fines to developers who comply with the legal rules.
\end{abstract}

Keyword: Undue accusations. Environmental administrative infraction. Legal insecurity of developers. State environmental legislation. São Paulo allotments.

\section{INTRODUÇÃO}

É notório o aumento vertiginoso de loteamentos que se espalham pelos diversos municípios paulistas, em razão do crescimento populacional experimentado pelo vigoroso desenvolvimento econômico e social nas últimas décadas em nosso país. Só em 2016, segundo o órgão que aprova os projetos de loteamentos paulista GRAPOHAB - Grupo de Análise e Aprovação de Projetos Habitacionais do Estado de São Paulo, foram aprovados 460 projetos, num total de 133.170 lotes ofertados (SECOVI, 2017)

\footnotetext{
${ }^{1}$ UNIFEV

${ }^{2}$ Universidade Brasil
} 
Nesse mister, atuam as empresas que se dedicam a realizar os loteamentos, com altos investimentos, visando lucro, mas obrigadas a cumprir rigorosa legislação para obter o licenciamento ambiental em respeito a um dos mais importantes valores sociais que é o meio ambiente.

Embora se desvencilhem de todas as obrigações legais, cumprindo com todas as rigorosas exigências previstas no ordenamento jurídico, referidas empresas são surpreendidas com acusações de infração administrativas e advertências ou multas pela Companhia Ambiental de São Paulo (CETESB, 2017) por um fato que não praticaram, dele não participaram, nem obtiveram qualquer vantagem direta ou indireta de qualquer natureza e nem mesmo tinham poder para evitar, causando inconformismo não só no aspecto econômico, mas também no aspecto da segurança jurídica, provocado pela aplicação equivocada de uma legislação controvertida. Esta contradição é aparente na legislação paulista, especialmente na Lei Estadual no 997 de 31 de maio de 1976 (SÃO PAULO, 1976) e em seu regulamento o Decreto n 8.468 de 08 de setembro de 1976 (SÃO PAULO, 1976a), na medida em que, ora veda e ora permite a ocupação de loteamentos antes da Licença de Operação, gerando uma insegurança jurídica para as empresas loteadoras diante de uma crise normativa que culmina com a aplicação de multas.

Deste modo, este trabalho tem por escopo examinar a legislação estadual paulista acerca do licenciamento ambiental de loteamentos regulares no que toca à sua ocupação antes da licença final denominada Licença de Operação, bem como as sanções aplicadas aos loteadores pelo órgão ambiental competente como base na suposta infração administrativa ambiental.

\section{MATERIAL E MÉTODO}

\section{Abrangência}

Considerando a análise da legislação paulista acerca das infrações administrativas ambientais aplicadas a loteamentos, o trabalho foi desenvolvido no âmbito do Estado de São Paulo.

\section{Levantamento de dados na CETESB - Companhia Ambiental do Estado de São Paulo}

Foi realizada uma pesquisa de autos de infração e imposição de advertências ou multas em loteamentos do Estado de São Paulo, nos anos de 2013 até 2016, em razão da ocupação antes da licença de operação. Trata-se de dados públicos cuja utilização, principalmente para fins de pesquisa científica, independem de prévia autorização, publicados no site da CETESB.

\section{Transcrição e tabulação dos dados}

Após obtenção das informações junto a CETESB - Companhia Ambiental do Estado de São Paulo, as mesmas foram transcritas e tabuladas em planilhas eletrônicas (software Excel) para posterior tratamento.

\section{Avaliação da imposição de multas em loteamentos no Estado de São Paulo}

Após tabulados, os dados foram avaliados buscando analisar a imposição de advertências ou multas em loteamentos no Estado de São Paulo, em razão da ocupação antes da licença de operação.

\section{Proposta de nova intepretação ou de melhoria na Lei no 997/76}

Baseado nos resultados obtidos com o levantamento de dados e avaliação da imposição de multas em loteamentos no Estado de São Paulo, em razão da ocupação antes da licença de operação, foi desenvolvido um texto referente a uma pequena alteração na legislação estadual para dar mais clareza, no sentido de que, se o loteamento já está com as obras de infraestrutura totalmente concluídas, sua ocupação passa a ser permitida antes mesmo da Licença de Operação e que a infração administrativa ambiental se caracterize apenas quanto houve dolo ou culpa do agente. 


\section{RESULTADO E DISCUSSÃO}

\section{LEVANTAMENTO DE DADOS NA CETESB - COMPANHIA AMBIENTAL DO ESTADO DE SÃO PAULO}

Foram identificados 802 autos de infração e imposição de penalidades aplicados pela CETESB (CETESB, 2017) a diversas prefeituras e inúmeros loteadores responsáveis por loteamentos localizados em dezenas de cidades do Estado de São Paulo, no período de 2013 a 2016, pela infração específica de ocupação de loteamentos antes da licença de operação prevista no art. 62, inciso IV, do Decreto $\mathrm{n}^{\circ}$ $8.468 / 76$.

Foi possível constatar uma variação das penalidades impostas, de mera advertência a multa pecuniária, o que revela falta de uniformidade de conduta dos agentes ambientais quanto à correta sanção a ser aplicada e ampla discricionariedade na sanção a ser imposta.

Do total dos autos de infração, em 721 foi aplicada a penalidade de advertência, enquanto em 81 foi aplicada a penalidade de multa, cujo valor não consta no referido banco de dados.

Em 2013 foram 103 advertências e 33 multas. Em 2014 foram 153 advertências e 35 multas. Em 2015 foram 164 advertências e 60 multas. E em 2016 foram 187 advertências e 60 multas.

Embora a Lei paulista $n^{\circ} 997 / 76$, em seu artigo $7^{\circ}$, disponha que a infração será classificada como leve, grave ou gravíssima, de acordo com os critérios da intensidade do dano, efetivo ou potencial, das circunstâncias atenuantes ou agravantes e dos antecedentes do infrator, não foi possível revelar quais os critérios utilizados pelos fiscais da CETESB.

Foi possível constatar ainda que, do total de 802 autos de infração lavrados pela CETESB no referido período, 721 foram contra os loteadores e ou proprietários da área onde foi instalado o loteamento, enquanto 81 foram contra as prefeituras municipais.

Essa constatação registra que a CETESB acusa de infração administrativa ambiental muito mais os loteadores do que as prefeituras municipais, muito embora as ocupações consideradas indevidas sejam diretamente autorizadas pelas próprias prefeituras que, no caso, são exclusivamente as responsáveis ao expedir para os compradores dos lotes os alvarás de construção. Expede o alvará de construção pois essa é sua atribuição e não dar a licença de ocupação, a premissa está errada, pois é o loteador que tem que realizar as obras e não as Prefeituras.

Não obstante, foi possível constatar um número imensamente maior de meras advertências em relação às multas, revelando que em sua grande maioria as infrações provavelmente são classificadas como leves.

Por outro lado, dividindo-se, na medida do possível, as infrações pelas cidades em que são lavrados os autos de infração, constatou-se que a cidade com o maior número de infrações lavradas foi a capital São Paulo, seguida de São José do Rio Preto, Campinas, Sales, em conjunto Olímpia, Marília e Paulínia, seguidas de centenas de outras cidades espalhadas pelo território paulista.

Com exceção da capital, verifica-se que a quantidade de autos de infração não é proporcional à população das cidades, mas provavelmente proporcional ao número de loteamentos em execução durante o período analisado.

\section{COMPORTAMENTO DO ÓRGÃO AMBIENTAL PAULISTA CETESB}

A Administração Pública paulista, através de seu órgão responsável que é a CETESB, tem adotado comportamento inadequado diante de loteadores, acusando-lhes de infração administrativa ambiental 
consistente na ocupação de loteamentos antes da devida licença de operação, com a imposição de advertências e multas pecuniárias. Inadequado porque:

2.1 Contraria a ordem jurídica constitucional e infraconstitucional, na medida em que, ainda que tacitamente, aplica indevidamente a teoria da responsabilidade objetiva, quando na realidade incide a responsabilidade subjetiva.

2.2 Contraria a ordem jurídica infraconstitucional, na medida em que a ocupação de loteamentos antes da licença de operação, desde que concluídas todas as obras de infraestrutura do empreendimento, é permitida por expressa ressalva constante do art. 66 do Decreto $n^{\circ} 8.468 / 76$. Se é permitido não é ilícito, e se não é ilícito não há infração.

2.3 Acusa o loteador de infração sem que tenha havido qualquer conduta voluntária no sentido de descumprir a norma, pois a ocupação é realizada pelo comprador do lote com base em alvará de construção expedido pela prefeitura municipal, situação que não guarda nexo de causalidade com conduta alguma do loteador, seja comissiva ou omissiva. Nenhuma omissão pode ser imputada ao loteador, que não detém poder de polícia nem poderia impedir a prefeitura de praticar ato administrativo e nem impedir o comprador a construir devidamente autorizado. A suposta infração (ocupação) não guarda nexo com omissão do loteador.

2.4 Acusa o loteador sem a devida perquirição acerca de sua culpabilidade, desprezando que não houve dolo nem culpa, não houve intenção nem negligência em relação à ocupação do loteamento.

2.5 Faz tábula rasa da excludente de responsabilidade consistente no fato de terceiro, já que a situação descrita na norma como infração decorre de ato exclusivo de terceiros (prefeitura municipal e comprador do lote), sem qualquer participação do loteador, direta ou indireta.

2.6 Não considera o fato de que a ocupação do loteamento dotado de infraestrutura não tem potencial de degradação ao meio ambiente, o verdadeiro pano de fundo das normas sancionadoras por violação do dever de prevenção e proteção ao meio ambiente.

2.7 Despreza novamente a norma estadual, ao não observar que o loteador não praticou o ato, não concorreu para a prática do ato e nem se beneficiou do ato.

A Administração Pública paulista faz questão de não enxergar a mensagem do texto constitucional e o conjunto da legislação infraconstitucional de que a responsabilidade por infração administrativa ambiental é subjetiva.

Isso porque os agentes fiscais têm suas condutas balizadas pela natureza subjetiva eleita pelo legislador estadual, ficando sem espaço para a discricionariedade na acusação de infrações e aplicação de sanções, ao contrário do que sói acontece no Estado de São Paulo.

\section{PROPOSTA DE NOVO EIXO DE INTERPRETAÇÃO E DE ALTERAÇÕES NA LEGISLAÇÃO PAULISTA VIGENTE SOBRE INFRAÇÕES ADMINISTRATIVAS AMBIENTAIS}

Necessário, de início, explicitar as circunstâncias da situação sob exame para perfeita delimitação do problema, a saber:

3.1 loteamentos paulistas com a infraestrutura básica totalmente concluída e atestada pelo órgão competente;

3.2 licença de Operação ainda não expedida;

3.3 alvarás de construção de casas expedidos pela prefeitura, a pedido dos compradores dos lotes e em favor destes; 
3.4 ocupação do loteamento pelos compradores ao construírem suas casas sobre os lotes e nelas morar.

Ante tais circunstâncias, passa-se ao devido exame.

É curial, no Direito, o conhecimento de que a conduta humana, individualmente considerada, pode gerar efeitos diversos no campo das responsabilidades, aqui compreendida, a responsabilidade, como sujeição da pessoa às consequências advindas de sua conduta.

Traz ínsita a noção natural de que à toda ação, comissiva ou omissiva, corresponde uma reação. Não é diferente na seara ambiental.

A Constituição Federal da República Federativa do Brasil (BRASIL, 1988) dedica um capítulo ao meio ambiente, cujo artigo 225 principia o caráter axiológico do direito social ao meio ambiente ecologicamente equilibrado, impondo a todos, Poder Público e coletividade, o dever de defendê-lo e preservá-lo para as gerações presentes e futuras. Logo em seguida, em seu $\S 3^{\circ}$, referido dispositivo constitucional prevê que a pessoa infratora que praticar atos considerados lesivos ao meio ambiente ficará sujeita a sanções penais e administrativas, independentemente da obrigação de reparar os danos causados. (BRASIL, 1988)

Depreende-se do texto constitucional que a conduta ou atividade lesiva ao meio ambiente é reprovável e deve sujeitar a pessoa infratora a sanções, a penalidades, no âmbito penal e administrativo, sem prejuízo da indenização no âmbito civil pelos danos causados. Este plexo é a tríade das responsabilidades.

A um só tempo e pelo mesmo ato praticado, a pessoa infratora pode responder na área do Direito Penal (pena restritiva de liberdade), do Direito Administrativo (pena de multa) e do Direito Civil (indenização), de forma cumulativa ou não.

Ao dispor que a obrigação de reparação de danos independe das sanções penais e administrativas, o texto constitucional revela a adoção da pena sem culpa, ou seja, a teoria da responsabilidade objetiva segundo a qual a pessoa, direta ou indiretamente ligada aos danos, tem a obrigação de repará-los independentemente de ter agido com dolo ou culpa.

É o que se denota, aliás, da expressa previsão legal contida na lei que trata da PNMA, cujo $\S 1^{\circ}$ do art. 14 estabelece que sem obstar a aplicação das penalidades previstas neste artigo, é o poluidor obrigado, independentemente da existência de culpa, a indenizar ou reparar os danos causados ao meio ambiente e a terceiros, afetados por sua atividade. (BRASIL, 1981)

A previsão contida no referido $\S 1^{\circ}$ se arvora no que a doutrina denomina de teoria do risco integral, segundo a qual, além da responsabilidade ser objetiva, não se admitem as excludentes de ilicitude para se furtar à reparação dos danos, tais como caso fortuito, força maior e fato de terceiro.

Bem externa a questão Steigleder, Milaré e Machado (2011), fazendo menção a respeitáveis doutrinadores da área:

A teoria do risco integral originalmente legitimou a responsabilidade objetiva e proclama a reparação do dano mesmo involuntário, responsabilizando-se o agente por todo ato do qual fosse a causa material, excetuando-se apenas os fatos exteriores ao homem. Trata-se nas palavras de Caio Mário da Silva Pereira, "de uma tese puramente negativista. Não cogita de indagar como ou porque ocorreu o dano. É suficiente apurar se houve o dano, vinculado a um fato qualquer, para assegurar à vítima uma indenização". Comentando esta teoria, Lucarelli refere que "a indenização é devida somente pelo fato de existir a atividade da qual adveio o prejuízo, independentemente da análise da subjetividade do agente, sendo possível responsabilizar todos aqueles aos quais possa, de alguma maneira, ser imputado o prejuízo. Esse posicionamento não admite excludentes de responsabilidade, tais como o caso fortuito, a força maior, a ação de terceiros ou da própria vítima", posto que tais acontecimentos são considerados "condições" do 
evento.A adoção desta teoria é justificada pelo âmbito de proteção outorgado pelo art. 225, caput, da CF de 1988, ao meio ambiente ecologicamente equilibrado, podendo-se vislumbrar a instituição de uma verdadeira obrigação de incolumidade sobre os bens ambientais. Trata-se de entendimento defendido por Antônio Herman Benjamin, Jorge Nunes Athias, Sérgio Cavalieri Filho, Édis Milaré, Nelson Nery Jr., José Afonso da Silva, Sérgio Ferraz.

E a jurisprudência pacífica encontra-se registrada no julgamento do Recurso Especial $\mathrm{n}^{\mathrm{o}}$ 1.354.536, do Superior Tribunal de Justiça, julgado no regime dos recursos repetitivos, cujo trecho da ementa do acórdão é abaixo reproduzida:

RESPONSABILIDADE CIVIL POR DANO AMBIENTAL. RECURSO ESPECIAL REPRESENTATIVO DE CONTROVÉRSIA. ART. 543-C DO CPC. DANOS DECORRENTES DE VAZAMENTO DE AMÔNIA NO RIO SERGIPE. ACIDENTE AMBIENTAL OCORRIDO EM OUTUBRO DE 2008. 1. Para fins do art. 543-C do Código de Processo Civil: ... b) a responsabilidade por dano ambiental é objetiva, informada pela teoria do risco integral, sendo o nexo de causalidade o fator aglutinante que permite que o risco se integre na unidade do ato, sendo descabida a invocação, pela empresa responsável pelo dano ambiental, de excludentes de responsabilidade civil para afastar a sua obrigação de indenizar; .... (SUPERIOR TRIBUNAL DE JUSTIÇA, 2014)

Enquanto a responsabilidade civil de reparação de danos causados ao meio ambiente, fundada na teoria objetiva do risco integral, encontra-se pacificada na doutrina e na jurisprudência, a responsabilidade administrativa e a responsabilidade penal não encontram consenso quanto à natureza objetiva ou subjetiva.

À discussão quanto à natureza jurídica da responsabilidade administrativa, precede a questão do princípio constitucional da legalidade, especialmente o da tipicidade, segundo o qual somente existirá infração se a conduta considerada infratora estiver previamente definida em lei como tal.

É o que se dessume das normas de que ninguém é obrigado a fazer ou deixar de fazer alguma coisa senão em virtude de lei, e de que a Administração Pública deve atuar de acordo com o princípio da legalidade. Ambas as normas estão previstas, respectivamente, no artigo $5^{\circ}$, inciso II, e na cabeça do artigo 37 da Constituição Federal (BRASIL, 1988).

A responsabilidade administrativa ambiental nasce do descumprimento de uma norma legal, de forma que a conduta tida como infratora deve estar expressamente prevista na lei. É a subsunção do fato à norma, para fins de gerar a sanção.

Milaré (2014), com sua sabedoria, ensina que "Desse modo, os pressupostos para a configuração da responsabilidade administrativa podem ser sintetizados na fórmula conduta ilícita, considerada como qualquer comportamento contrário ao ordenamento jurídico".

A configuração da infração administrativa, para fins de responsabilização, depende da voluntariedade da conduta do sujeito infrator, tanto é que a infração administrativa é conceituada como " $o$ descumprimento voluntário de uma norma administrativa para o qual se prevê sanção cuja imposição é decidida por uma autoridade no exercício de função administrativa”. (MELLO, 2015)

Entretanto, no que concerne ao requisito da culpabilidade (dolo ou culpa), se também é necessário ou não para a caracterização da infração administrativa ambiental e para a imposição da respectiva sanção, há intenso e caloroso debate doutrinário e jurisprudencial entre a corrente que ora adota a teoria da responsabilidade objetiva, com suas vertentes, e a corrente antagônica que adota a teoria da responsabilidade subjetiva.

Antes da exposição das correntes doutrinárias e jurisprudenciais, importante ressaltar as normas legais acerca da questão.

A Constituição Federal, no $\S 3^{\circ}$ do art. 225, não revela, de forma clara e inequívoca, se as sanções 
penais e administrativas têm natureza objetiva ou subjetiva.

Já a lei federal que trata da PNMA, em seu artigo 14, estabelece que sem prejuizo das penalidades definidas pela legislação federal, estadual e municipal, o não cumprimento das medidas necessárias à preservação ou correção dos inconvenientes e danos causados pela degradação da qualidade ambiental sujeitará os transgressores a sanções administrativas (BRASIL, 1981), de forma que, pelo menos à primeira vista, parece trilhar o caminho da subjetividade ao silenciar na cabeça do referido artigo, já que em $\S 1^{\circ}$, ao tratar da responsabilidade civil pela reparação de danos, é explícito na adoção da responsabilidade objetiva, até mesmo porque na responsabilidade administrativa usa a expressão transgressor, enquanto na responsabilidade civil usa a expressão poluidor, revelando tratamento distinto entre a mera transgressão da norma e a transgressão da norma acompanhada de degradação ambiental (poluidor).

As infrações administrativas ambientais estão disciplinadas pela Lei Federal no 9.605 de 12 de fevereiro de 1998, que dispõe sobre as sanções penais e administrativas derivadas de condutas $e$ atividades lesivas ao meio ambiente e dá outras providências. (BRASIL, 1998)

A cabeça do artigo 70 da referida lei, ao dispor que considera-se infração administrativa ambiental toda ação ou omissão que viole as regras jurídicas de uso, gozo, promoção, proteção e recuperação do meio ambiente, parece revelar a adoção da teoria da responsabilidade objetiva, bastando a voluntariedade para configuração da infração, independentemente de dolo ou culpa.

Tanto é que, ao dispor sobre a sanção de multa simples, entre diversas outras previstas, o $\S 3^{\circ}$ do artigo 72 da referida lei estabelece que a mesma será aplicada sempre que a pessoa agir com negligência ou dolo, revelando, de modo inequívoco, a adoção da teoria da responsabilidade subjetiva. (BRASIL, 1998)

Referidas normas, portanto, são campo fértil para as divergências.

Mais uma vez, destaca-se a objetividade de Mello (2015), no sentido de que "É muito discutido em doutrina se basta a mera voluntariedade para configurar a exigência de um ilícito administrativo sancionável, ou se haveria necessidade ao menos de culpa. Quando menos, até o presente, temos entendido que basta a voluntariedade, sem prejuízo, como é claro, da lei estabelecer exigência maior perante a figura tal ou qual". Para este autor, que adota a teoria da responsabilidade objetiva, voluntariedade é o "animus de praticar dada conduta", quando existe a possibilidade de prévia ciência e prévia eleição do comportamento a ser adotado.

Meirelles (2016) adota, em linhas gerais, a responsabilidade administrativa ambiental objetiva, ao afirmar que "a multa administrativa é de natureza objetiva e se torna devida independentemente da ocorrência de dolo ou culpa do infrator".

Interessante a posição da AGU - Advocacia Geral da União, na Orientação Jurídica Normativa ${ }^{\circ}$ 26/2011/PFE/IBAMA, para quem a responsabilidade administrativa é objetiva, porém baseada na teoria do risco criado e não do risco integral, admitindo-se, pois, as excludentes. Eis a ementa:

As normas legais aplicáveis para sancionar condutas lesivas ao meio ambiente, a saber, arts. 70 a 72, da Lei Federal $n^{\circ}$ 9.605/98, não preveem a comprovação de elementos subjetivos para a configuração da infração; Na responsabilidade civil ambiental adota-se a Teoria do Risco Integral, a qual não admite excludentes de responsabilidade, tais como força maior, caso fortuito ou fato de terceiro. Lado outro, a responsabilidade administrativa baseia-se na Teoria do Risco Criado, que admite a incidência de excludentes, mas exige do administrado - ante a presunção de legitimidade dos atos administrativos - que demonstre que seu comportamento não contribuiu para a ocorrência da infração (culpa concorrente). (AGU, 2011) 
Na mesma linha e de forma semelhante entre ambos, Freitas (2014) e Machado (2014), para quem a regra é a responsabilidade objetiva e a culpa é exceção, sendo que das diversas sanções descritas no art. 72 da Lei 9.605/98 (BRASIL, 1998), a única que exige culpa ou dolo é a multa simples.

Das 10 sanções previstas no art. 72 da Lei 9.605/1998 (incisos I a XI), somente a multa simples utilizará o critério da responsabilidade com culpa; e as outras nove sanções, inclusive a multa diária, irão utilizar o critério da responsabilidade sem culpa ou objetiva, continuando a seguir o sistema da lei 6.938/1981, onde não há necessidade de serem aferidos o dolo e a negligência do infrator submetido ao processo. (MACHADO, 2014)

De outra banda, Osório (2015) segue a linha da subjetividade, fazendo um paralelo entre a sanção penal e a sanção administrativa e concluindo pela existência do princípio da culpabilidade agasalhado pela Constituição Federal, ao afirmar que:

Se uma infração disciplinar é, 'in concreto', inevitável, qual é o fundamento para a suposta atividade corretiva do Estado? Corrigir o quê? Se a ação ilícita era, por qualquer motivo, inevitável, como punir o infrator, se a ideia é reeducar no âmbito das sanções disciplinares? Daí se vê a importância transcendental da culpabilidade. Evitabilidade do fato é, portanto, o fundamento mais próximo da exigência da culpabilidade. Para que alguém possa ser administrativamente sancionado ou punido, ..., necessário que o agente se revele culpável.

[...]

Ficaria o princípio da culpabilidade adstrito, na produção de seus efeitos e reflexos, ao campo penal? Parece-me evidente que não. E isso porque tal princípio não tem natureza essencialmente penal, mas sim constitucional. É um princípio constitucional genérico, que limita o poder punitivo do Estado. Trata-se, nesse passo, de garantia individual contra o arbítrio, garantia que se corporifica em direitos fundamentais da pessoa humana.

$\mathrm{Na}$ mesma linha Bim (2010), para quem: "Um dos princípios de direito administrativo sancionador é o da culpabilidade, o que se traduz como exigência de dolo ou culpa para aplicar a sanção administrativa (...)".

Também Vitta (2008), para quem: "todo ilícito administrativo ou penal, exige, no regime democrático de direito, o elemento subjetivo [vale dizer, a culpa] do suposto infrator", de forma que "no regime jurídico-constitucionnal desse porte, no qual se acentuam a República, a Democracia e o Estado de Direito, não podemos conceber haja infrações administrativas, diante de mera voluntariedade, se qualquer análise da culpa ou do dolo do infrator".

É o que também esclarece Teixeira (2008), em artigo científico, embora sintético, mas de profunda importância: "É de se notar que o texto constitucional foi de cristalina clareza ao segregar, no plano ambiental, as responsabilidades civil, administrativa e penal, guindando a primeira, pela dicção do $\S 2^{\circ}$, do art. 225, à categoria objetiva, pela notória aplicação da teoria do risco, enquanto que as duas últimas (administrativa e penal), como não poderia deixar de ser, encontram-se vinculadas à subjetividade da conduta da pessoa que praticou a lesão ambiental, consoante o disposto no $\S 3^{\circ}$, do art. 225."

Na mesma senda, Moraes (2004) afirma que: "na volúpia que se tem na proteção do meio ambiente .... disseminou-se a utilização da teoria da responsabilização civil objetiva para punir por simples presunção a pessoa ligada à atividade ou propriedade onde ocorreu a infração ambiental. Desdobrando: é responsável o proprietário do imóvel, o empresário, a empresa, simplesmente por ter ocorrido alguma infração naquele local, s em que em nenhum momento se tenha havido preocupação 
de se estabelecer a autoria, a qual é elemento básico da i mputação, pois a necessidade de averiguação da culpa é posterior a se encontrar o autor da conduta infracional".

Ainda na mesma linha comunga o insígne Justem Filho (2013), para quem: "O Estado Democrático de Direito exclui o sancionamento punitivo dissociado da comprovação da culpabilidade. Não se pode admitir a punição apenas em virtude da concretização de uma ocorrência danosa material.

Pune-se porque alguém agiu mal, de modo reprovável, em termos antissociais. (...) Portanto, não basta a mera verificação da ocorrência objetiva de um evento danoso. É imperioso avaliar a dimensão subjetiva da conduta do agente (...)."

Novamente Osório (2015) ensina que: “(...) Culpabilidade é uma exigência inarredável, para as pessoas físicas ou mesmo jurídicas, decorrente da fórmula substancial do devido processo legal e da necessária proporcionalidade das infrações e das sanções, sendo imprescindível uma análise da subjetividade do autor do fato ilícito, quando se trate de pessoa humana, e da exigibilidade de conduta diversa, além da intencionalidade perceptível ou previsibilidade do resultado danoso, quando se trate de pessoa jurídica. (...) Repele-se, fundamentalmente, a responsabilidade pelo fato de outrem e a responsabilidade objetiva. $O$ delito é obra do homem, como é a infração administrativa praticada por pessoa física, sendo inconstitucional qualquer lei que despreze o princípio da responsabilidade subjetiva."

A nosso ver, o contexto constitucional não se coaduna com a ideia de que alguém possa ser responsabilizado administrativamente sem ter agido com culpa ou por ato praticado por terceiro. A responsabilidade decorrente do direito punitivo ou sancionador volta os olhos para a conduta humana e sua penalização, enquanto a responsabilidade civil do direito ressarcitório volta os olhos para o dano e sua reparação.

Se a situação fática descrita na lei como infração administrativa não foi provocada pela pessoa acusada, nem poderia ser por ela evitada, não pode haver responsabilização.

Em excelente trabalho, Mello defende que não basta a mera voluntariedade para caracterização da infração e imposição da sanção, exigindo-se a culpabilidade. Este autor distingue a sanção administrativa retributiva (multa simples) da sanção administrativa ressarcitória (multa penal e juros moratórios), para dizer que a sanção retributiva tem finalidade preventiva, no sentido de estimular uma mudança de comportamento do infrator para que não repita o erro. Conclui que "Em suma, a sanção administrativa retributiva aplicada a sujeito que agiu sem dolo ou culpa, mas apenas com voluntariedade, não vai atingir seu fim preventivo, mostrando-se inadequada e, portanto, ofensiva ao princípio constitucional da proporcionalidade." (MELLO, R. 2005)

Uma outra via interpretativa é a de que, embora a responsabilidade por infração administrativa ambiental seja subjetiva, a culpa é presumida, de forma que ocorre a inversão do ônus da prova no sentido de que cabe à Administração Pública apurar a infração e impor a sanção, mas admitindo-se que a pessoa acusada possa comprovar a ausência de culpabilidade (dolo ou culpa) para se eximir da responsabilização, isso porque a finalidade da sanção administrativa é a correção de um erro de conduta, dado seu caráter pedagógico.

Escorreita, a esse respeito, a posição de Teixeira (2008): "Em sede administrativa, todavia, a questão da responsabilidade assume contorno totalmente diverso porquanto, aqui, mais do que o aspecto puramente ressarcitório, busca-se, através da sanção, balizar o comportamento do administrado, razão pela qual o componente da culpabilidade ganha forte relevância na caracterização da infração na medida em que traduz uma ação que, de alguma forma, poderia e deveria ser evitada. Depreende-se ser a sanção na mais que a consequência destinada a um sujeito em função de uma atitude de descumprimento da conduta esperada perante o ordenamento jurídico. $O$ objetivo das sanções, tanto criminais como 
administrativas, é intimidar potenciais infratores (prevenção geral) e punir aquele que descumpriu o mandamento normativo, para que não reincida (prevenção especial)."

E conclui:

\begin{abstract}
A questão sub ocullis foi bem enfrentada por Rodrigo Tostes de Alencar Mascarenhas que observou da necessidade de se fazer a distinção entre, de um lado, a exigência da ocorrência de culpa ou dolo como elemento necessário a configurar a existência da infração e, de outro lado, a questão de saber a quem cabe o ônus da prova. Comparando com a presunção de certeza e liquidez que goza a dívida ativa regularmente inscrita, conclui o autor que mesmo na fase administrativa é aplicável a presunção de veracidade e de legitimidade de que gozam os atos administrativos em geral, e, por fim, que além da presunção que goza o auto, a culpa é presumível em diversas hipóteses, cabendo ao infrator demonstrar que esta não ocorreu.

Consentânea com as modernas teorias da responsabilidade civil, a inversão do ônus da prova, nas infrações administrativas ambientais resolve uma questão crucial para a configuração desse grau de responsabilidade que é a fragilidade do meio ambiente diante da ação predatória do indivíduo, fazendo com que suposto infrator demonstre que agiu dentro das cautelas que a ordem jurídica impõe.
\end{abstract}

Na seara jurisprudencial, o Superior Tribunal de Justiça aplica a teoria da responsabilidade subjetiva às infrações administrativas ambientais, conforme se vê no julgamento do Recurso Especial $n^{\circ}$ 1.401.500, com origem no Estado do Paraná, proferido pela $2^{\mathrm{a}}$ Turma e por unanimidade, conforme ementa a seguir transcrita:

PROCESSUAL CIVIL. AMBIENTAL. EXPLOSÃO DE NAVIO NA BAÍA DE PARANAGUÁ (NAVIO "VICUNA"). VAZAMENTO DE METANOL E ÓLEOS COMBUSTÍVEIS. OCORRÊNCIA DE GRAVES DANOS AMBIENTAIS. AUTUAÇÃO PELO INSTITUTO AMBIENTAL DO PARANÁ (IAP) DA EMPRESA QUE IMPORTOU O PRODUTO "METANOL". ART. 535 DO CPC. VIOLAÇÃO. OCORRÊNCIA. EMBARGOS DE DECLARAÇÃO. AUSÊNCIA DE MANIFESTAÇÃO PELO TRIBUNAL A QUO. QUESTÃO RELEVANTE PARA A SOLUÇÃO DA LIDE. $1 \ldots 2 \ldots 3 \ldots$

4. Todavia, os presentes autos tratam de questão diversa, a saber a natureza da responsabilidade administrativa ambiental, bem omo a demonstração de existência ou não de culpa, já que a controvérsia é referente ao cabimento ou não de multa administrativa.

5. Sendo assim, o STJ possui jurisprudência no sentido de que, "tratando-se e responsabilidade administrativa ambiental, o terceiro, proprietário da carga, por não ser o efetivo causador do dano ambiental, responde subjetivamente pela degradação ambiental causada pelo transportador" (AgRg no AREsp 62.584/RJ, Rel. Ministro Sérgio Kukina, Rel. p/ acórdão Ministra Regina Helena Costa, Primeira Turma, DJe 7.10.2015).

6. "Isso porque a aplicação de penalidades administrativas não obedece à lógica da responsabilidade objetiva da esfera cível (para reparação dos danos causados), as deve obedecer à sistemática da teoria da culpabilidade, ou seja, a conduta deve ser cometida pelo alegado transgressor, com demonstração de seu elemento subjetivo, e com demonstração do nexo causal entre a conduta e o dano". (REsp 1.251.697/PR, Rel. Ministro Mauro Campbell Marques, Segunda Turma, DJe 17.4.2012). (SUPERIOR TRIBUNAL DE JUSTIÇA, 2016)

O Supremo Tribunal Federal, em decisão da $1^{\text {a }}$ Turma capitaneada pela Ministra Rosa Weber, no julgamento do Recurso Extraordinário $n^{\circ} 548.181$, decidiu pela responsabilidade penal objetiva da pessoa jurídica, sendo desnecessária a vinculação a uma ação humana, de forma a prescindir da presença de uma pessoa natural (física) na denúncia da ação penal.

RECURSO EXTRAORDINÁRIO. DIREITO PENAL. CRIME AMBIENTAL. RESPONSABILIDADE PENAL DA PESSOA JURÍDICA. CONDICIONAMENTO DA AÇÃO PENAL À IDENTIFICAÇÃO E À PERSECUÇÃO CONCOMITANTE DA 
PESSOA FÍSICA QUE NÃO ENCONTRA AMPARO NA CONSTITUIÇÃO DA REPÚBLICA.

1. O art. $225, \S 3^{\circ}$, da Constituição Federal não condiciona a responsabilização penal da pessoa jurídica por crimes ambientais à simultânea persecução penal da pessoa física em tese responsável no âmbito da empresa. A norma constitucional não impõe a necessária dupla imputação.

2. As organizações corporativas complexas da atualidade se caracterizam pela descentralização e distribuição de atribuições e responsabilidades, sendo inerentes, a esta realidade, as dificuldades para imputar o fato ilícito a uma pessoa concreta.

3. Condicionar a aplicação do art. $225, \S 3^{\circ}$, da Carta Política a uma concreta imputação também a pessoa física implica indevida restrição da norma constitucional, expressa a intenção do constituinte originário não apenas de ampliar o alcance das sanções penais, mas também de evitar a impunidade pelos crimes ambientais frente às imensas dificuldades de individualização dos responsáveis internamente às corporações, além de reforçar a tutela do bem jurídico ambiental.

4. A identificação dos setores e agentes internos da empresa determinantes da produção do fato ilícito tem relevância e deve ser buscada no caso concreto como forma de esclarecer se esses indivíduos ou órgãos atuaram ou deliberaram no exercício regular de suas atribuições internas à sociedade, e ainda para verificar se a atuação se deu no interesse ou em benefício da entidade coletiva. Tal esclarecimento, relevante para fins de imputar determinado delito à pessoa jurídica, não se confunde, todavia, com subordinar a responsabilização da pessoa jurídica à responsabilização conjunta e cumulativa das pessoas físicas envolvidas. Em não raras oportunidades, as responsabilidades internas pelo fato estarão diluídas ou parcializadas de tal modo que não permitirão a imputação de responsabilidade penal individual.

5. Recurso Extraordinário parcialmente conhecido e, na parte conhecida, provido. (SUPREMO TRIBUNAL FEDERAL, 2014)

Importante ressaltar que no referido julgamento, a teoria da culpabilidade foi afastada para permitir a acusação de infração penal contra pessoa jurídica, mesmo sem a presença de uma determinada pessoa natural. Entretanto e com o devido respeito a quem entende de forma diversa, referido julgamento não pode servir de norte para a aplicação da responsabilidade objetiva para infrações administrativas ambientais. Aliás, o ministro Marco Aurélio, vencido no julgamento, alertou: "Fico a imaginar, uma vez selada a culpa da Petrobrás, quem será escalado para cumprir a pena! Continuo convencido de que estamos gastando vela com um péssimo defunto."

Feita essa digressão sobre a doutrina e a jurisprudência acerca do tema, indispensável para as discussões deste trabalho a legislação estadual paulista sobre as infrações administrativas ambientais.

O Estado de São Paulo, a despeito de não possuir uma legislação própria que define e caracteriza as infrações administrativas ambientais, apropriou-se do conteúdo da Lei Federal $n^{\circ}$ 9.605/98 por meio do Decreto $\mathrm{n}^{\circ}$ 60.342/2014 editado pelo Governador do Estado, que dispõe sobre o procedimento para imposição de penalidades, no âmbito do Sistema Estadual de Administração da Qualidade Ambiental, Proteção, Controle e Desenvolvimento do Meio Ambiente e uso Adequado dos Recursos Naturais SEAQUA, e dá outras providências. (SÃO PAULO, 2014).

Assim, as análises e conclusões que se extraírem da legislação federal sobre a interpretação das infrações administrativas ambientais também se aplicam, em razão do princípio da simetria, à legislação paulista.

A Lei Estadual $n^{\circ}$ 997/76 traz no parágrafo único do artigo $7^{\circ}$, uma regra que também não informa, com a devida segurança, sobre a necessidade ou não de culpabilidade, ao dispor que responderá pela infração quem por qualquer modo a cometer, concorrer para sua prática ou dela se beneficar. (SÃO PAULO, 1976) 
No governo fluminense o tratamento da questão é diferente. No Estado do Rio de Janeiro vige a Lei $\mathrm{n}^{\circ} 3.467$, de 14 de setembro de 2.000, a qual dispõe sobre as sanções administrativas derivadas de condutas lesivas ao meio ambiente no Estado do Rio de Janeiro, e dá outras providências (RIO DE JANEIRO, 2000).

Na referida lei consta expressamente que a infração administrativa ambiental decorre de uma ação ou omissão "dolosa ou culposa" que viole as regras jurídicas do meio ambiente, de forma que resta claro que o governo fluminense adotou de forma explícita a teoria da responsabilidade administrativa subjetiva, elegendo a culpabilidade como elemento constitutivo da infração administrativa.

Denota-se que referida lei fluminense encontra-se em conformidade com o texto constitucional que trata da responsabilidade administrativa por infrações ambientais, exigindo a culpabilidade para sua caracterização, revelando maior segurança jurídica para empreendedores e evitando acusações e sanções indevidas.

Sob as influências das teorias retro mencionadas, não há como não admitir que a melhor corrente e mais consentânea com o texto constitucional é a que exige a culpabilidade nas infrações administrativas ambientais, até mesmo porque encontra amparo na jurisprudência do Superior Tribunal de Justiça.

De qualquer forma, ainda que seja aplicada a responsabilidade objetiva e por estar fundada na teoria do risco criado e não do risco integral, são admissíveis as chamadas excludentes de responsabilidade que passam a ser esclarecidas.

Não se pode olvidar das chamadas excludentes de ilicitude, situações capazes de afastar a caracterização da infração ou a aplicação da sanção, enfim afastar a responsabilidade de quem não agiu com dolo ou culpa.

Entre elas, o Código Penal, veiculado pelo Decreto-Lei $n^{\circ} 2.848$ de 7 de dezembro de 1940 (BRASIL, 1940), cujo art. 23 prevê como excludentes de ilicitude e, por isso, não caracterizam crime, a legítima defesa, o estado de necessidade, o exercício regular de direito e o estrito cumprimento do dever legal.

Já o Código Civil, veiculado pela Lei no 10.406 de 10 de janeiro de 2002 (BRASIL, 2002), no seu artigo 88, repete a legítima defesa, o estado de necessidade e o exercício regular de direito como situações que afastam a ilicitude do ato, enquanto no seu artigo 393 exclui a responsabilidade em razão de caso fortuito ou de força maior.

Por sua vez, o Código de Defesa do Consumidor veiculado pela Lei n 8.078 de 11 de setembro de 1990 (BRASIL, 1990), por sua vez, em seus artigos 12, § $3^{\circ}$, III, e 14, § $3^{\circ}$, II, prevê a culpa exclusiva da vítima ou de terceiro como causa excludente de responsabilidade.

Para a questão objeto deste trabalho, importa o fato de terceiro como excludente da responsabilidade administrativa ambiental por infração sujeita a multa simples. Para que o fato de terceiro seja admitido como excludente da responsabilidade, é necessário que o terceiro seja o causador exclusivo da situação prevista na norma como infração administrativa ambiental e que o fato seja inevitável e imprevisível, pois só assim será possível eliminar o nexo causal com a conduta do agente.

Teixeira (2008) arremata:

No tocante à responsabilidade administrativa, onde a função precípua da sanção é pedagógica, sendo adotado o sistema da culpa presumida para imputação das infrações ambientais, incidem, igualmente, as prefaladas excludentes de responsabilidade, em especial o caso fortuito, a força maior e o fato de terceiro.

Assim explanados os elementos constitutivos da infração administrativa ambiental e as excludentes de ilicitude, é chegado o momento de analisar a ocupação de loteamentos antes da expedição da Licença de Operação. 
Segundo a ressalva expressa que consta no Decreto paulista $n^{\circ} 8.468 / 76$, em seu artigo 66, para loteamentos com as obras de infraestrutura concluídas, a prefeitura municipal pode expedir o alvará de construção mesmo antes da licença de operação.

Neste aspecto, se a ocupação do loteamento sem a prévia licença de operação é expressamente permitida pela norma jurídica, não há que se falar em ato ilícito, desde sua origem.

Sem ilícito, não há infração alguma porque esta pressupõe o descumprimento da norma.

Ainda que pudesse ser caracterizada a ilicitude da ocupação de loteamentos, sob tais circunstâncias, antes da licença de operação, o que se admite apenas em remota hipótese e por amor ao debate, é nítida a ausência de voluntariedade.

Isso porque não houve, por parte do loteador, qualquer ato voluntário, com animus próprio e de forma consciente, descrito na norma como infração administrativa sujeita a sanção.

Sem a voluntariedade, que é pressuposto para a caracterização da infração administrativa, tanto que a infração é definida como o descumprimento voluntário da norma, não há se falar em infração e, portanto, em responsabilização para imposição de sanção.

Nem mesmo por omissão poderia o loteador ser acusado.

A omissão, para justificar a caracterização da infração, há de ser relevante e estar contida no nexo de causalidade entre a conduta omissiva (o que se deixou de fazer) e o resultado previsto na norma sancionadora, de modo a ser previsível e evitável.

A ocupação, que é realizada pelos adquirentes de lotes com base em alvarás de construção expedidos pela prefeitura municipal, não guarda absolutamente relação alguma com quaisquer condutas do loteador, não decorre da inércia do loteador, mas de expressa previsão legal.

Embora fosse até previsível, eis que a própria norma do decreto estadual autoriza a prefeitura a emitir o alvará de construção para adquirentes de lotes antes mesmo da licença de operação, mas desde que estejam totalmente concluídas as obras de infraestrutura, a situação descrita na norma sancionadora é inevitável.

O loteador não detém poder de polícia para impedir a prefeitura de expedir o alvará de construção, cujo ato está autorizado por norma estadual e se insere na discricionariedade administrativa de verificar se o projeto atende ou não às posturas municipais.

Também não possui o loteador o poder de impedir que o adquirente do lote erga a construção porque é direito seu, reconhecido e expressamente autorizado pelo órgão público competente, que é a prefeitura municipal, por meio do devido alvará de construção.

Bem examinada a questão, até mesmo sob a perspectiva da questão ambiental, que é a verdadeira questão de fundo, a construção das casas e consequente moradia - a ocupação a que se refere a lei, não traria nem teria o potencial de trazer qualquer risco de degradação ao meio ambiente.

Isso porque todas as obras de infraestrutura do loteamento estão concluídas, de forma que a correta captação, utilização e destinação da água e do esgoto sanitário está garantida pela existência das redes públicas de água e esgoto.

Ademais, há que se considerar que a ocorrência da situação prevista na norma como infração ocupação do loteamento antes da licença de operação - foi total e exclusivamente provocada por fato de terceiro, no caso, pela prefeitura municipal e pelo adquirente do lote.

Frise-se, novamente, que o loteador não praticou tal conduta, não concorreu para a prática de tal conduta e não se beneficiou de tal conduta.

Nenhuma vantagem pode ser atribuída ao loteador em decorrência da ocupação do loteamento, pois a vantagem na realização de um loteamento, para o loteador, por óbvio, advém da comercialização dos lotes, cuja venda é permitida desde o efetivo registro do loteamento perante o Registro de Imóveis, o 
Que ocorre quando o empreendimento está em fase inicial, até mesmo antes do início das obras de infraestrutura.

Assim, para evitar que ocorram e se repitam tais ilegalidades e injustiças, este trabalho recomenda uma nova postura da Administração Pública na interpretação da norma constitucional, no caso específico ao órgão estadual da CETESB que verifique as circunstâncias subjacentes e inerentes à culpabilidade antes de acusar de infração e aplicar multa a loteadores, certificando-se de que os mesmos não tenham praticado qualquer ato, comissivo ou omissivo, por dolo ou culpa, capaz de propiciar a suposta infração.

Sendo inviável ou considerada inadmissível essa nova visão de interpretação da legislação vigente, propor a alteração no texto da Lei $\mathrm{n}^{\circ} 997 / 76$ para inserir ao final do inciso IV do artigo 62 do Decreto $n^{\circ} 8.468 / 76$ a expressão "ou da devida atestação da conclusão total das obras de infraestrutura" e inserir ao final do parágrafo único do artigo $7^{\circ}$ a expressão "por dolo ou culpa".

\section{CONCLUSÃO}

Com a realização deste trabalho, pode-se notar a importância da correta leitura e interpretação do ordenamento jurídico, principalmente por parte da Administração Pública, não podendo atropelar a lei para fins arrecadatórios, acusando e multando indevidamente loteadores que cumprem as regras legais, executando as obras de acordo com os projetos previamente aprovados, colaborando com a expansão urbana em total respeito ao desenvolvimento sustentável.

Também pode-se notar a importância da necessária alteração na legislação paulista vigente, de fim de eliminar qualquer dúvida sobre a possibilidade de ocupação de loteamentos antes da licença de operação, desde que concluídas satisfatoriamente as obras de infraestrutura, até mesmo porque não haveria qualquer risco de degradação ambiental.

Diante desta proposta, haveria maior segurança jurídica para as prefeituras e para os loteadores.

\section{REFERÊNCIAS}

AGU. ADVOCACIA GERAL DA UNIÃO. Orientação jurídica normativa nº 26/2011/PFE/IBAMA. Disponível em: <www.agu.gov.br/page/download/index/id/3999674>. Acesso em: 13 nov. 2017.

\section{BIM, E. F. O mito da responsabilidade objetiva no direito ambiental sancionador:} imprescindibilidade de culpa nas infrações ambientais. Revista de Direito Ambiental, Revista dos Tribunais, 2010, nº 57, p. 69.

BRASIL. Decreto-Lei no 2.848 de 07 de dezembro de 1940. Institui o Código Penal. Disponível em: <http://www2.camara.leg.br/legin/fed/declei/1940-1949/decreto-lei-2848-7-dezembro-1940-412868publicacaooriginal-1-pe.html>. Acesso em: 13 nov. 2017.

BRASIL. Lei Federal n ${ }^{\circ} 6.015$ de 31 de dezembro de 1973. Dispõe sobre os registros públicos e dá outras providências. Disponível em: <http://www.planalto.gov.br/ccivil_03/leis/L6015compilada.htm>. Acesso em: 13 nov. 2017.

BRASIL. Lei Federal n 6.766 de 19 de dezembro de 1979. Dispõe sobre o parcelamento do solo urbano e dá outras providências. Disponível em: <http://www.planalto.gov.br/ccivil_03/leis/L6766.htm>. Acesso em: 13 nov. 2017. 
BRASIL. Lei Federal no 6.938 de 31 de agosto de 1981. Dispõe sobre a Política Nacional do Meio Ambiente, seus fins e mecanismos de formulação e aplicação, e dá outras providências. Disponível em: <http://www.planalto.gov.br/ccivil_03/leis/L6938.htm>. Acesso em: 13 nov. 2017.

BRASIL. Constituição Federal da República Federativa do Brasil, de 05 de outubro de 1988. Disponível em: <http://www.planalto.gov.br/ccivil_03/constituicao/constituicao.htm〉. Acesso em: 13 nov. 2017.

BRASIL. Lei Federal no 8.078 de 11 de setembro de 1990. Dispõe sobre a proteção do consumidor e dá outras providências. Disponível em: <http://www.planalto.gov.br/ccivil_03/leis/L8078.htm>. Acesso em: 13 nov. 2017.

BRASIL. Ministério do Meio Ambiente. Conselho Nacional do Meio Ambiente - CONAMA. Resolução n 237 de 19 de dezembro de 1997. Disponível em: 〈http://www.mma.gov.br/port/conama/index.cfm>. Acesso em: 07 jul. 2017.

BRASIL. Lei Federal n ${ }^{\circ} 9.605$ de 12 de fevereiro de 1998. Dispõe sobre as sanções penais e administrativas derivadas de condutas e atividades lesivas ao meio ambiente e dá outras providências. Disponível em: <http://www.planalto.gov.br/ccivil_03/leis/L9605.htm〉. Acesso em: 13 nov. 2017.

BRASIL. Lei Federal no 10.257 de 10 de julho de 2001. Regulamenta os arts. 182 e 183 da Constituição Federal, estabelece diretrizes gerais da política urbana e dá outras providências. Disponível em: <http://www.planalto.gov.br/ccivil_03/leis/LEIS_2001/L10257.htm>. Acesso em: 13 nov. 2017.

BRASIL. Lei Federal no 10.406 de 10 de janeiro de 2002. Institui o Código Civil. Disponível em: <http://www.planalto.gov.br/ccivil_03/leis/2002/L10406.htm>. Acesso em: 13 nov. 2017.

CETESB. Companhia Ambiental do Estado de São Paulo. Disponível em:

<http://cetesb.sp.gov.br/documentos-emitidos/autuacoes/\#1502477391293-f4610500-a9b4)>. Acesso em: 02 out. 2017.

COPAM. Conselho Estadual de Política Ambiental do Estado de Minas Gerais. Deliberação Normativa ${ }^{\circ}$ 58 de 28 de novembro de 2002. Estabelece normas para o licenciamento ambiental de loteamento do solo urbano para uso predominantemente residencial e dá outras providências. Disponível em: <https://www.pjf.mg.gov.br/secretarias/sma/legislacao/arquivos/dn_58_2002.pdf〉. Acesso em 12 nov. 2017.

FREITAS, V. P. Direito administrativo e meio ambiente. 5. ed. Paraná: Juruá, 2014.

JUSTEN FILHO, M. Curso de Direito Administrativo. 9 ed. São Paulo: Revista dos Tribunais, 2013, pp. $613 / 614$.

MACHADO, P. A. L. Direito Ambiental Brasileiro. 20. ed. São Paulo: Malheiros, 2014, p. 374.

MAXIMILIANO, C. Hermenêutica e Aplicação do Direito. 21 ed. Rio de Janeiro: Forense, 2017.

MEIRELLES, H. L. Direito Administrativo Brasileiro. 42 ed. São Paulo: Malheiros, 2016.

MILARÉ, É. Direito do Ambiente: A Gestão Ambiental em foco. 9.ed.. São Paulo: Revista dos Tribunais, 2014. p.420.

MELLO, C. A. B. Curso de Direito Administrativo, 32ª ed. - Ed. Malheiros, São Paulo, 2015.

MELLO, R. M. Sanção administrativa e o princípio da culpabilidade. A\&C. Revista de Direito Administrativo \& Constitucional. Belo Horizonte: ano 5, n. 22, out/dez 2005. Disponível em: <http://www.revistaaec.com/index.php/revistaaec/article/viewFile/624/77>. Acesso em: 13 nov. 2017.

MORAES, L. C. S. Curso de Direito Ambiental. 2 ed. São Paulo: Atlas, 2004, pp. 124/125. 
OSÓRIO, F. M. Direito Administrativo Sancionador, 5. ed. São Paulo: Revista dos Tribunais, 2015.

RIO DE JANEIRO. Lei $n^{\circ} 3.467$, de 14 de setembro de 2.000, a qual dispõe sobre as sanções administrativas derivadas de condutas lesivas ao meio ambiente no Estado do Rio de Janeiro, e dá outras providências. Disponível em: 〈https://gov-rj.jusbrasil.com.br/legislacao/193334/lei-3467-00>. Acesso em 02 out. 2017.

SÃO PAULO. Lei Estadual no 997 de 31 de maio de 1976. Dispõe sobre o controle de poluição do meio ambiente. Disponível em: <https://www.al.sp.gov.br/norma/?id=46075>. Acesso em 12 nov. 2017.

SÃO PAULO. Decreto n 8.468 de 08 de setembro de 1976a. Aprova o regulamento da Lei $n^{\circ}$ 997, de 31 de maio de 1976, que dispõe sobre a prevenção e o controle de poluição do meio ambiente. Disponível em: 〈http://licenciamento.cetesb.sp.gov.br/legislacao/estadual/decretos/1976_Dec_Est_8468.pdf〉. Acesso em 12 nov. 2017.

SÃO PAULO. Decreto n 52.053 de 13 de agosto de 2007. Reestrutura o Grupo de Análise e Aprovação de Projetos Habitacionais - GRAPROHAB e dá providências correlatas. Disponível em:

$\langle$ http://licenciamento.cetesb.sp.gov.br/legislacao/estadual/decretos/2007_Dec_Est_52053.pdf〉.Acesso em 12 nov. 2017.

SÃO PAULO. Decreto n 60.342 de 4 de abril de 2014. Dispõe sobre o procedimento para imposição de penalidades, no âmbito do Sistema Estadual de Administração da Qualidade Ambiental, Proteção,

Controle e Desenvolvimento do Meio Ambiente e uso Adequado dos Recursos Naturais - SEAQUA, e dá outras providências. Disponível em: <https://www.al.sp.gov.br/norma/?id=172692>. Acesso em 12 nov. 2017.

SECOVI. Sindicato das Empresas de Compra, Venda, Locação e Administração de Imóveis. Disponível em: $\langle$ https://www.secovi.com.br/downloads/pesquisas-e-indices/graprohab/graprohab-2016.pdf >. Acesso em: 02 out. 2017.

STEIGLEDER, A. M. MILARÉ, É. MACHADO, P. A. L.. Doutrinas essenciais de direito ambiental: responsabilidade em matéria ambiental. São Paulo: Revista dos Tribunais, v. V, 2011.

SUPERIOR TRIBUNAL DE JUSTIÇA. Recurso Especial n ${ }^{\circ}$ 1.354.536. Recorrente: Maria Gomes de Oliveira. Recorrido: Petróleo Brasileiro S/A PETROBBRÁS. Publicado no Diário da Justiça Eletrônico em 05.05.2014. Disponível em: <

https://ww2.stj.jus.br/processo/revista/documento/mediado/?componente=ATC\&sequencial=35174776\&n um_registro=201202466478\&data=20140505\&tipo=5\&formato=PDF $>$. Acesso em: 18 nov. 2017.

SUPERIOR TRIBUNAL DE JUSTIÇA. Recurso Especial n 1.401.500. Recorrente: Hexion Química Indústria e Comércio Ltda. Recorrido: Instituto Ambiental do Paraná - IAP. Publicado no Diário da Justiça Eletrônico em 13.09.2016. Disponível em:

$<$ https://ww2.stj.jus.br/processo/revista/documento/mediado/?componente=ATC\&sequencial=62818311\& num_registro $=201302931370 \&$ data $=20160913 \&$ tipo $=5 \&$ formato $=P D F>$. Acesso em: 18 nov. 2017.

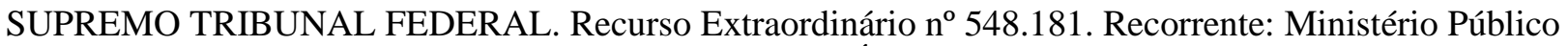
Federal. Recorrida: Petróleo Brasileiro S/A - PETROBRÁS. Publicado no Diário da Justiça Eletrônico em 30.10.2014. Disponível em:

<http://redir.stf.jus.br/paginadorpub/paginador.jsp?docTP=TP\&docID=7087018>.Acesso em:18 nov.2017

TEIXEIRA, R. Revista de Direito, editada pela Procuradoria Geral do Estado do Rio de Janeiro, vol. 63, 2008, páginas 255/265. Disponível em: <https://www.pge.ri.gov.br/revista-de-direito/2008-volume63>. Acesso em 27 set. 2017.

VITTA, H. G. Responsabilidade civil e administrativa por dano ambiental. São Paulo: Malheiros, 2008. p. 159. 
VOTUPORANGA (SP). Lei Municipal no 2.830 de 05 de janeiro de 1996. Dispõe sobre o Sistema disciplinar e institui normas gerais de zoneamento, parcelamento, uso e ocupação de solo, aplicáveis no município. Disponível em:

<http://www.votuporanga.sp.gov.br/atool/_arquivo/pasta/fc3cf452d3da8402bebb765225ce8c0e.pdf >. Acesso em 12 nov. 2017. 